\title{
Comparison of model forms for estimating stem taper and volume in the primary conifer species of the North American Acadian Region
}

\author{
Rongxia LI*, Aaron R. WEISKITTEL \\ School of Forest Resources, University of Maine, Orono, ME 04469-5755, USA
}

(Received 3 February 2009; accepted 18 August 2009)

Keywords:

balsam fir /

red spruce /

white pine /

nonlinear mixed-effects /

crown variables
Mots-clés :

sapin baumier /

épinette rouge /

pin Weymouth /

effets mixtes non linéaires /

variables de la couronne

\begin{abstract}
- The performance of ten commonly used taper equations for predicting both stem form and volume in balsam fir [Abies balsamea (L.) Mill], red spruce[Picea rubens (Sarg.)], and white pine[Pinus strobus (L.)] in the Acadian Region of North America was investigated.

- Results show that the Kozak (2004) and Bi (2000) equations were superior to the other equations in predicting diameter inside bark for red spruce and white pine, while the Valentine and Gregoire (2001) equation performed slightly better for balsam fir.

- For stem volume, the Clark et al. (1991) equation provided the best predictions across all species when upper stem diameter measurements were available, while the Kozak (2004) and compatible taper equation of Fang et al. (2000) performed well when those measurements were unavailable.

- The incorporation of crown variables substantially improved stem volume predictions (mean absolute bias reduction of $7-15 \%$; root mean square error reduction of $10-15 \%$ ) for all three species, but had little impact on stem form predictions.

- The best taper equation reduced the predicted root mean square error by 16,39 , and $45 \%$ compared to estimates from the widely used Honer (1965) regional stem volume equations for balsam fir, red spruce, and white pine, respectively.

- When multiple taper equations exist for a certain species, the use of the geometric mean of all predictions is an attractive alternative to selecting the "best" equation.
\end{abstract}

Résumé - Comparaison de formules modèles pour estimer la décroissance de la tige et le volume des principales espèces de conifères dans la région de l'Acadie en Amérique du Nord.

- Les performances de dix équations de la décroissance de la tige, couramment utilisées pour prédire à la fois la forme du tronc et le volume pour le sapin baumier [Abies balsamea (L.) Mill], l'Épinette rouge [Picea rubens (Sarg.)], et le pin Weymouth [Pinus strobus (L.)] ont été étudiées dans la région de l'Acadie en Amérique du Nord.

- Les résultats montrent que les équations de Kozak (2004) et de Bi (2000) étaient supérieures aux autres équations pour la prédiction du diamètre sous écorce pour l'épinette rouge et le pin Weymouth, tandis que l'équation de Valentine et Gregoire (2001) était légèrement meilleure pour la forme du tronc du sapin baumier.

- Pour le volume de la tige, l'équation de Clark et al. (1991) fourni les meilleures prévisions pour toutes les espèces lorsque les mesures du diamètre de la partie supérieure de la tige étaient disponibles, tandis que l'équation de Kozak (2004) et l'équation compatible de défilement de Fang et al. (2000) conviennent bien lorsque ces mesures n'étaient pas disponibles.

- L'incorporation de variables de couronne a amélioré sensiblement les prédictions du volume des troncs (réduction moyenne des biais absolu de 7-15\%; réduction de l'erreur quadratique moyenne de 10-15\%) pour les trois espèces, mais avait peu d'impact sur les prédictions de la forme du tronc. - La meilleure équation de décroissance a réduit l'estimation de l'erreur quadratique moyenne de 16, 39 , et $45 \%$ par rapport aux estimations largement utilisées avec les équations régionales d'Honer (1965) pour l'estimation du volume de la tige respectivement pour le sapin baumier, l'épinette rouge et le pin Weymouth.

- Lorsque plusieurs équations de défilement existent pour certaines espèces, l'utilisation de la moyenne géométrique de toutes les prédictions est une alternative intéressante pour la sélection de la "meilleure" équation.

\footnotetext{
*Corresponding author: Rongxia.Li@umit.maine.edu
} 


\section{INTRODUCTION}

Taper equations provide diameter inside (dib) or outside bark (dob) estimates at any given height along a tree bole (Clutter et al., 1983). The ability of taper equations to estimate total and merchantable stem volume has long been a subject in the forestry literature. The advantage of estimating volume through taper equations over existing volume tables lies in the ability of taper equations to accurately predict the dob or dib at any given height of individual trees, hence allowing the acquisition of merchantable volume information to any desired specification.

Numerous taper model forms have been presented in the forestry literature over the past several decades. A very common approach in modeling the shape of a tree bole is to divide a tree into several sections, with each section corresponding to a regression function depicting stem diameter changes with increasing tree height. For example, Max and Burkhart (1976) proposed a segmented polynomial model that uses two joining points to link three stem sections along the bole: the lower section corresponding to a neiloid shape, the upper section corresponding to a conic shape, and the middle section corresponding to a parabolic shape. This idea has been widely accepted and used in many taper applications (Clark et al., 1991; Jiang et al., 2007; Leites and Robinson, 2004; Maguire and Batista, 1996). Kozak (Kozak 1988; 2004) and other researchers later introduced variable-exponent or variable-form taper equations which uses a changing exponent or a changing form to continuously describe the shape of a bole from the ground to the top, exhibiting more flexibility. Other types of taper equations can also be found in the literature such as polynomial (Kozak et al., 1969), trigonometric (Thomas and Parresol, 1991), and nonparametric (Lappi, 2006) approaches.

A well behaved taper equation should not only give unbiased estimates of dib or dob with a minimum variance, but also have flexibility to adapt to a wide variety of species and give accurate predictions of stem volume (Kozak and Smith, 1993). Most published taper equations were developed for a certain species and often their performance is compared to a limited number of alternative model forms. Therefore, it is necessary and beneficial to further study the characteristics of taper profile equations and extend their use to other species besides the ones for which they were originally developed. For example, Rojo et al. (2005) compared 31 different model forms on maritime pine [Pinus pinaster Ait.] in Spain and found variableform taper functions provided the most accurate predictions of dob, particularly the Kozak (2004) equation. However, Rojo et al. (2005) did not compare the taper equations' performance in predicting stem volume. Recent work by Diéguez-Aranda et al. (2006) and Corral-Rivas et al. (2007) have found that compatible taper equations such as the one suggested by Fang et al. (2000) work well for predicting both stem form and volume. Our study seeks to test whether these results hold across multiple species of varying shade tolerance levels and stand conditions.

The crown of a tree strongly influences its stem form because foliage provides carbohydrates for the tree growth and their vertical distribution influences stem formation (Larson, 1963). Crown size also determines the growth pattern along the stem as it influences the degree of wind pressure on the tree. However, there is no unified agreement on whether crown dimensions should be incorporated into taper equations as previous studies have shown mixed results on the benefits of adding crown variables in the taper models. Muhairwe et al. (1994) reported that the addition of crown ratio variable improved the fit and predictive abilities in the Kozak (1988) taper equation for lodgepole pine [Pinus contorta Dougl. ex. Loud], but found no improvement for several other species including aspen [Populus tremula (L.)], western redcedar [Thuja plicata Donn ex. D. Don] and Douglasfir [Pseudotsuga menziesii (Mirb.) Franco]. Muhairwe et al. (1994) also tested if an indicator variable for crown class improved the taper model and found no improvement for any of their 4 studied species. Leites and Robinson (2004) found a significant relationship between crown length, crown ratio, and the estimated random effects for the parameters in the Max and Burkhart (1976) taper equation for loblolly pine [Pinus taeda (L.)]. Jiang et al. (2005) also found that the addition of crown ratio as a predictor variable provided modest improvements for yellow-poplar [Liriodendron tulipifera (L.)], while Burkhart and Walton (1985) found no strong relationship between crown ratio and improved predictions for loblolly pine trees in unthinned stands. In our analysis, we attempt to determine if crown dimensions can improve predictions of both diameter and volume for several conifer species across a wide range of tree sizes and stand conditions.

In the Acadian Region of North America, which includes eastern Maine and part of eastern Canada, balsam fir [Abies balsamea (L.)], red spruce [Picea rubens Sarg.], and eastern white pine [Pinus strobus (L.)] are the three primary conifer species as they currently comprise over $30 \%$ of the net growth in Maine (McWilliams et al., 2005). However, a widely used regional taper equation does not currently exist and the Honer (1965) volume equations developed over four decades ago are still the most common tool used for estimating volume (Zakrzewski, 1999). Pitt and Lanteigne (2008) indicated that Honer (1965) volume equation tended to underestimate stem volume by over $11 \%$ on average and the bias increased with tree size for balsam fir, particularly in thinned stands. Recently, Weiskittel et al. (2009) found a similar level of bias in the Honer (1965) volume equation as well as several other additional volume equations available in the region for both balsam fir and red spruce.

The goal of this analysis was to develop stem taper equations for balsam fir, red spruce, and white pine in the Acadian Region. Specific objectives were to: (1) use mixed-effects to assess the amount of within- and between-tree variation in stem profiles; (2) evaluate ten widely used stem taper profile models for predicting both dib and total stem volume; and (3) assess the level of improvement across a range of species in dib and stem volume predictions with the incorporation of additional crown variables. 
Table I. Summary of tree attributes for balsam fir, red spruce, and white pine.

\begin{tabular}{|c|c|c|c|c|c|c|c|c|c|}
\hline & \multicolumn{3}{|c|}{ Balsam fir } & \multicolumn{3}{|c|}{ Red spruce } & \multicolumn{3}{|c|}{ White pine } \\
\hline & $D(\mathrm{~cm})$ & $H(\mathrm{~m})$ & $H C B(\mathrm{~cm})$ & $D(\mathrm{~cm})$ & $H(\mathrm{~m})$ & $H C B(\mathrm{~cm})$ & $D(\mathrm{~cm})$ & $H(\mathrm{~m})$ & $H C B(\mathrm{~cm})$ \\
\hline Max & 39.8 & 25.2 & 14.8 & 42.8 & 23.5 & 15.6 & 83.4 & 37.2 & 27.0 \\
\hline Std. & 5.7 & 3.3 & 2.6 & 6.2 & 3.2 & 2.6 & 13.9 & 6.6 & 4.7 \\
\hline
\end{tabular}

$D$ : Diameter outside bark at breast height. $H$ : Total tree height. HCB: Height to live crown base.

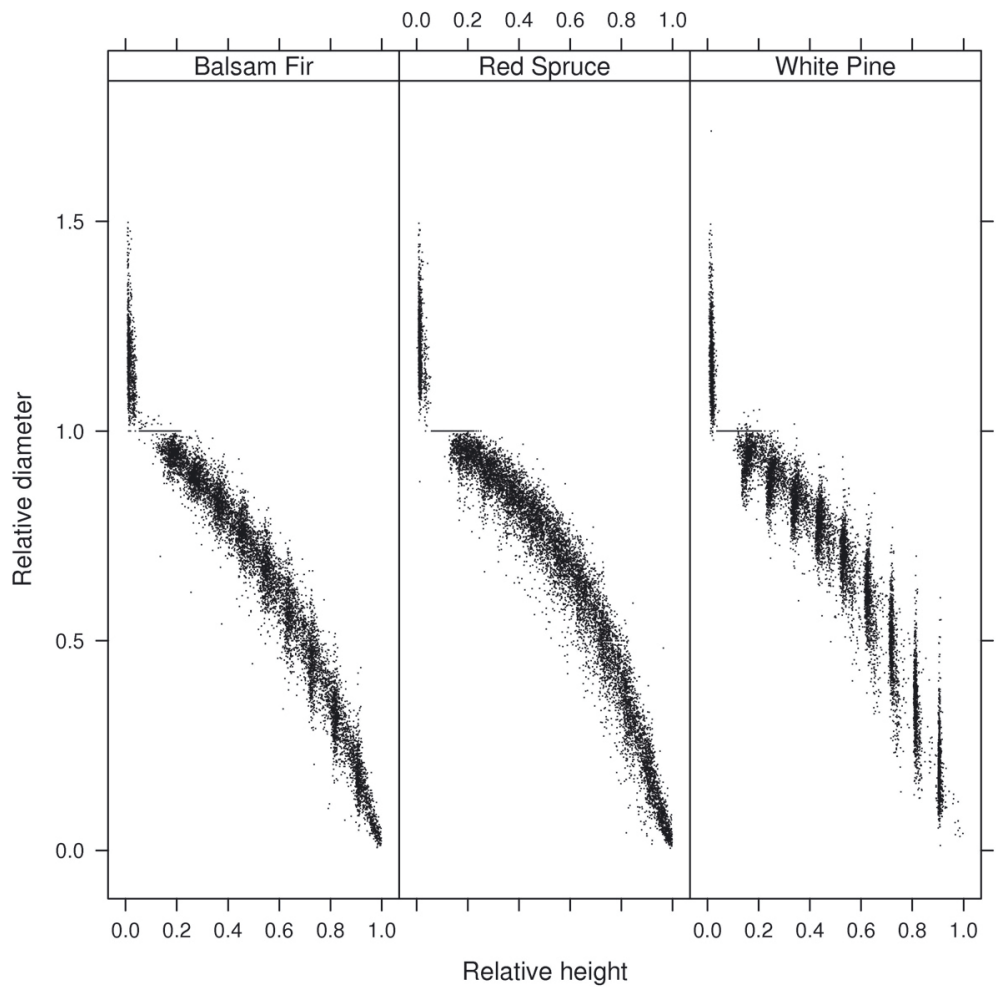

Figure 1. Scatter plots of the relative diameter (diameter inside bark/diameter inside bark at breast height) over relative height (stem height/total height) for species of balsam fir, red spruce, and white pine.

\section{METHODS}

\subsection{Data}

Stem analysis data were obtained from a variety of sources. For both balsam fir and red spruce, the stem data were gathered from Honer (1965), Vicary et al. (1984), Gilmore and Seymour (1996), Maguire et al. (1998), Phillips (2002), and Meyer (2005). Stem analysis data for white pine originated from Honer (1965) and Pace (2003). In total, there were 990 balsam fir, 1086 red spruce, and 949 white pine trees available for this analysis (Tab. I, Figs. 1, 2). A variety of sampling schemes were used in these studies and are briefly summarized below.

The Honer (1965) data were originally gathered for the construction of regional form-class volume tables for the Ontario Department of Lands and Forests. The trees were sampled in various sites throughout central and eastern Canada. The individual tree measurements were taken at stump, breast height, and every $1 / 10$ section above breast height. Both dib and dob as well as total tree height and height to live crown base were recorded. The dataset covered a wide range of stand types and ages.

The Vicary et al. (1984) data were originally collected between 1970 and 1977. Stands were located throughout eastern, northern, and western Maine. Most trees were younger than 50 years old at breast height and from even-aged sprucefir stands. The trees were felled and taper data were taken at

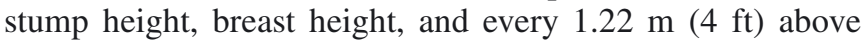
breast height with dib and dob measured at each section. The trees were systematically sampled to cover the range of diameters within a stand with emphasis on dominant and codominant individuals. Height to live crown base was recorded for most of the trees.

The Meyer (2005) data were collected during the summer of 2002 from 12 permanent research installations scattered throughout northeastern Maine. The trees were from 


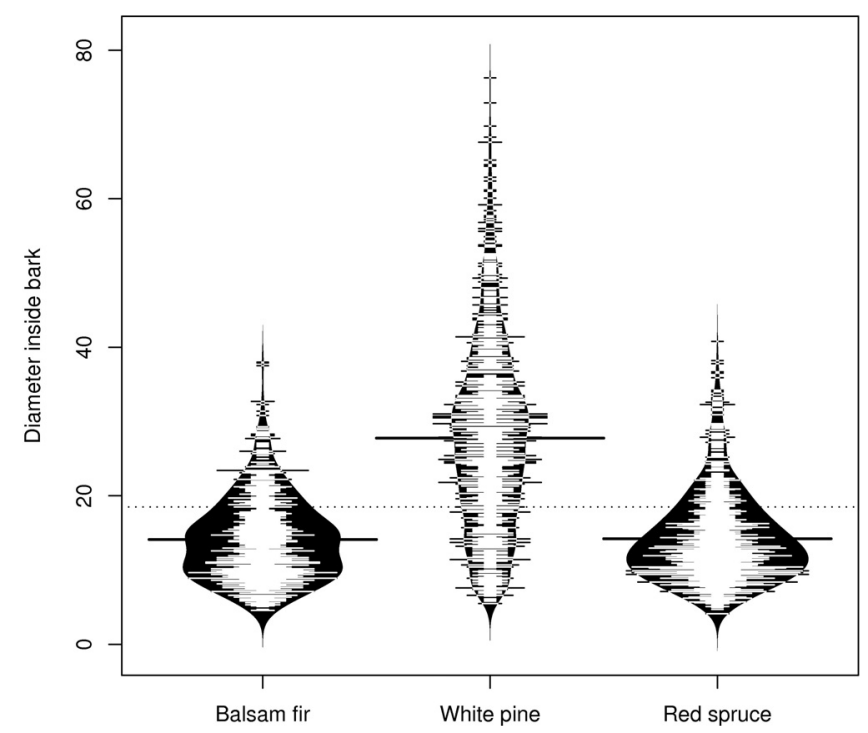

Figure 2. Bean plots for diameter inside bark balsam fir, red spruce, and white pine. The dotted line is the mean dib across species, while the black solid line is the mean for each individual species. The length of white horizontal bars represent the number of observations for a certain dib.

unthinned, even-aged stands of the spruce-fir forest type that were ready for either a precommercial or commercial thinning entry. Trees were taken from a variety of crown classes and DBH ranged from 4.9 to $34.3 \mathrm{~cm}$. The trees were felled and dib and dob measurements were made at stump height, breast height, and every $1 \mathrm{~m}$ above breast height.

Gilmore and Seymour (1996) and Pace (2003) study sites were located on the University of Maine Dwight B. Demeritt Forest, while the Maguire et al. (1998) and Phillips (2002) were on the nearby United States Forest Service Penobscot Experimental Forest. Both forests are within $10 \mathrm{~km}$ of Orono, Maine (44.89 N, 68.69 W) and border the central and southern climatic zones of the state (Briggs and Lemin, 1992). Stem analysis data was collected from a range of crown classes. Disks were sectioned from each tree at $0.15 \mathrm{~m}, 1 \mathrm{~m}, 1.3 \mathrm{~m}, 2 \mathrm{~m}$ and successive $1 \mathrm{~m}$ intervals to the tip of the tree. The stands were generally even-aged, with the exception of the Maguire et al. (1998) dataset.

The Phillips (2002) and Pace (2003) dataset included trees that were from both thinned and unthinned stands. Although thinning can influence stem taper in both balsam fir and red spruce, the impact is relatively minor and can largely be accounted for by a proper model form (Weiskittel et al., 2009).

\subsection{Taper equations}

Based on the analysis of Rojo et al. (2005) and DiéguezAranda et al. (2006), ten commonly used and well-behaved taper equations were selected for evaluation. They included: Max and Burkhart (1976), Kozak (2004) model 3 (referred to as Model 01), Kozak (2004) model 4 (referred to as Model 02), Bi (2000), Zakrzewski (1999), Valentine and Gregoire (2001),
Sharma and Zhang (2004), Sharma and Parton (2009), Clark et al. (1991) and Fang et al. (2000). The Max and Burkhart (1976) and Clark et al. (1991) are segmented taper equations, Fang et al. (2000) is a compatible volume-taper model with segmented-stem form factors, while all seven other taper equations are either variable exponent (Kozak, 2004; Sharma and Parton, 2009; Sharma and Zhang, 2004) or variable form (Bi, 2000; Valentine and Gregoire, 2001; Zakrzewski, 1999) (Tab. II).

In the Clark et al. (1991) equation, $F$ represents the dib measurement at the height of $5.27 \mathrm{~m}$. Given that taper equations that include upper stem measurements generally outperform ones that do not (Kozak, 1998), an equation was developed to predict the required upper stem measurements to ensure compatibility with the other examined taper equations. In the present analysis, diameters at $5.27 \mathrm{~m}$ were initially obtained through linear interpolation and then predicted for each tree using the equation forms presented in Jiang et al. (2005) as this measurement is generally not made during routine forest inventories. The upper diameter values at $5.27 \mathrm{~m}$ obtained from both steps (interpolation and prediction) were used in this study. The four identity functions in the Clark et al. (1991) equation were outlined as:

$$
\begin{aligned}
& I_{S}= \begin{cases}1 & \text { if } h<1.37 \\
0 & \text { otherwise }\end{cases} \\
& I_{B}= \begin{cases}1 & \text { if } 1.37<h<5.27 \\
0 & \text { otherwise }\end{cases} \\
& I_{T}= \begin{cases}1 & \text { if } h>5.27 \\
0 & \text { otherwise }\end{cases} \\
& I_{M}= \begin{cases}1 & \text { if } h<5.27+\beta_{5}(H-5.27) \\
0 & \text { otherwise. }\end{cases}
\end{aligned}
$$

\subsection{Statistical analysis}

Ordinary least squares is based on the assumption that the residual errors are independent and identically distributed. Stem taper data are hierarchical, collected at multiple points on the same individual tree. The autocorrelation among observations violates the assumption of independence. Neglect of this autocorrelation in modeling may incur severe consequences in statistical inference such as hypothesis tests and confidence intervals, because standard errors of parameter estimates provide an inappropriate assessment of estimation error (Davidian and Giltinan, 1995). Garber and Maguire (2003) stated that two methods are generally used to deal with autocorrelation issues with one method being directly modeling the time series correlation structure in the model fitting process, and the other method is to incorporate individual tree random effect in the model. The former can be implemented through generalized least squares and the latter is built in a mixed-effects model framework. Chi and Reinsel (1989) suggested to use both methods to address the within subject correlation because one method might not be adequate to fully eliminate the existing correlation among observations, which was also supported by the results of Garber and Maguire (2003). In the present 
Table II. Ten taper equations and their corresponding mathematical expressions.

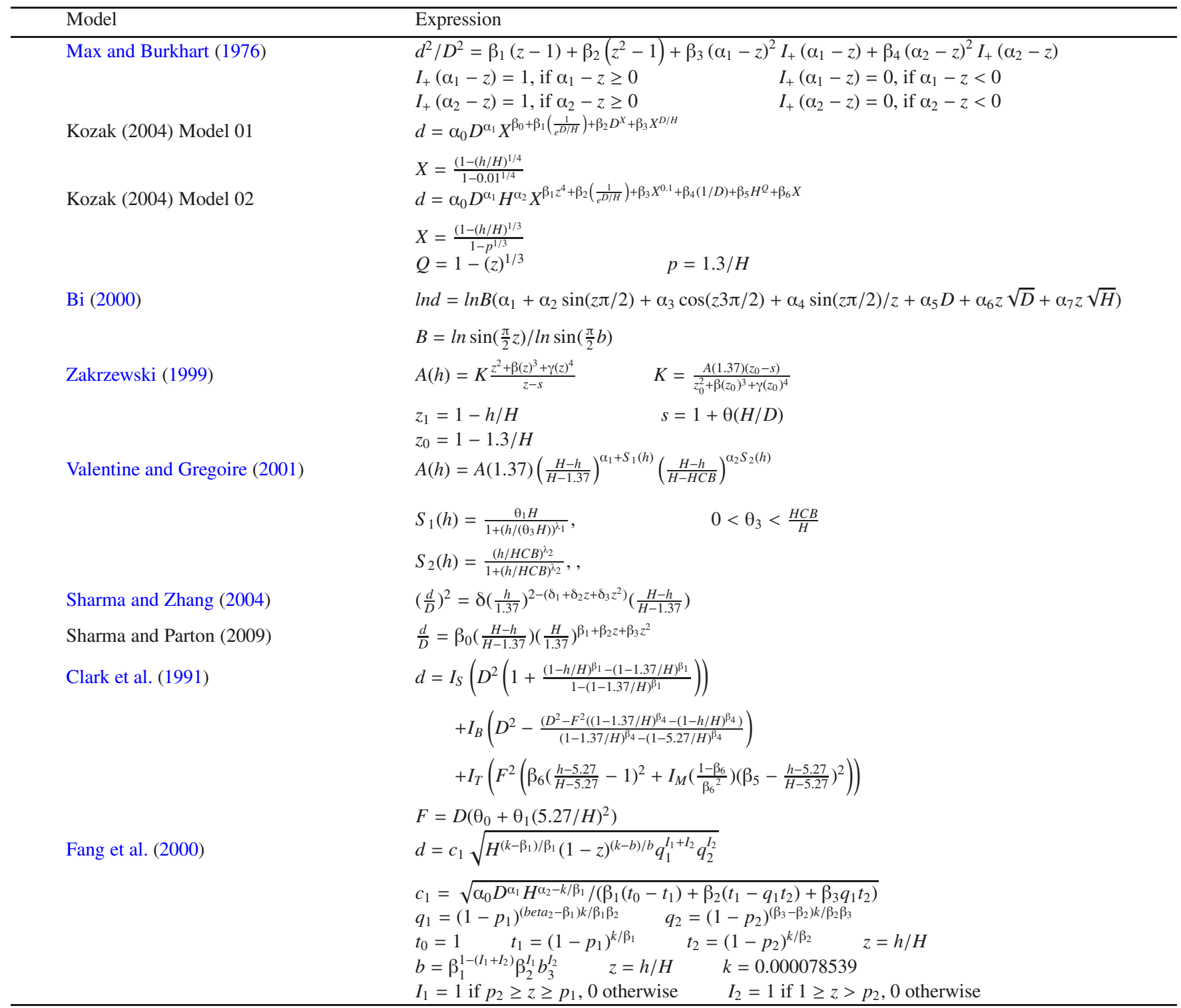

$H$ : Total tree height $(\mathrm{m}) ; D$ : diameter outside bark at breast height $(\mathrm{cm}) ; h$ : height above the ground $(\mathrm{m}) ; d$ : diameter inside bark at any given height $h(\mathrm{~cm}) ; A(1.37), A(h)$ : cross-sectional area at breast height and at height $h$, respectively; HCB: height to live crown base; $\alpha, \beta, \theta, \gamma, \delta, p$ : parameters to be estimated; $z: h / H$.

study, we considered both the inclusion of an autoregressive error structure specification and random effects.

Most often, the exact information of variance-covariance structure of the data is lacking, and thus an appropriate selection of correlation structure is critical. The most common intra-individual correlation structure used in forestry is the first-order autoregressive error structure (AR1). Because stem taper data were collected with an unequal distance along the bole, we opted to use the CAR1 correlation structure, which is a continuous version of AR1 and defined as:

$$
\operatorname{Corr}\left(\epsilon_{t}, \epsilon_{s}\right)=\phi^{|t-s|}
$$

where $\phi$ represents the correlation between two observations one unit apart, $t$ and $s$ refer two observational heights collected from the same tree, and $|t-s|$ is the distance between them. In other words, the value of correlation between two observations on the same tree depends on the absolute distance between them. This correlation structure can be used to describe unbalanced unequally spaced taper data (Gregoire et al., 1995). Other correlation structures were also tested in preliminary analysis and the results suggested minimal differences between the structures.

Mixed-effects models account for both the general population pattern through fixed effects and individual tree variation 
through random effects. Therefore, it maintains the flexibility to account for small between-tree variations without the loss of generality. Further, complicated variance-covariance structures can also be specified and included in the mixed-effects models to compensate the within tree auto-correlations that are not fully eliminated by random variables.

The mixed-effects model framework was formulized as follows:

$$
y_{i j}=f\left(\theta_{i j}, x_{i j}\right)+\epsilon_{i j}
$$

where

$$
\begin{aligned}
& i=1, \ldots, K \\
& j=1, \ldots, n_{i} \\
& \theta_{i j}=A_{i j}+Z_{i j} b_{i} \\
& b_{1}, \ldots, b_{K} \stackrel{i i d}{\sim} N(0, \Phi)
\end{aligned}
$$

here, $y_{i j}$ denotes the $j$ th observation on the $i$ th tree where we have $K$ trees in total, and $n_{i}$ observations in $i$ th group. $x_{i j}$ denotes a vector of covariates corresponding to response $y_{i j} . b_{i}$ is a vector of random effects for the $i$ th tree with a variancecovariance matrix $\Phi$. The matrices $A_{i j}$ and $Z_{i j}$ are model matrices for the fixed and random effects, respectively.

Within-tree variance heterogeneity in mixed-effects taper equations have been reported in the taper literature (e.g. Trincado and Burkhart (2006); Valentine and Gregoire (2001)). Preliminary analysis also indicated that heterogeneous variance existed in all fitted taper models, as the variance tended to increase with increasing diameters. To further improve parameter estimation, a power or an exponential variance function was used depending on the model form and the data, to take into account heteroscedasticity. These two variance functions were defined to be:

$$
\begin{gathered}
\operatorname{Var}\left(\epsilon_{i}\right)=\sigma^{2}\left|v_{i}\right|^{2 \delta} \\
\operatorname{Var}\left(\epsilon_{i}\right)=\sigma^{2} \exp \left(2 \delta v_{i}\right)
\end{gathered}
$$

where $\sigma^{2}$ is the residual sum of squares, $v_{i}$ is the weighting variable (relative height in the stem in this study), and $\delta$ is the variance function coefficient.

In short, the statistical analysis techniques of mixed-effects modeling were used in the present study with a specified correlation structure and a variance function to improve inference validation and increase prediction accuracy. Furthermore, mixed-effects models also depicted variations among different datasets, plots, and trees through random effects as well as describing the general population trend. Likelihood ratio tests indicated significant improvements in model fit $(p<0.0001)$ when both the correlation error structure and variance function were added.

\subsection{Evaluation criteria}

Akaike Information Criterion (AIC) and Bayesian Information Criterion (BIC) are two widely accepted goodness of fit criteria for comparing non-nested models (Gregoire et al., 1995 ) as they essentially represent a penalized likelihood criteria. Unfortunately, in this study they were not appropriate criteria for selecting and comparing taper functions, because the response variable for each taper function was not all the same (i.e. dib vs. dib/D). Therefore, AIC and BIC were only used to select appropriate submodels using the same taper equations with different formulations of random effects, covariance, and weight parameters.

Instead of using AIC or BIC, the performance of the taper equations were evaluated using mean absolute bias (MAB), root mean squared error (RMSE), and mean percentage of bias (MPB) as well as residual plots. MAB, RMSE, and MPB were calculated as:

$$
\begin{array}{r}
\mathrm{MAB}=\frac{1}{n} \sum_{i=1}^{n}\left|Y_{i}-\hat{Y}_{i}\right| \\
\mathrm{RMSE}=\sqrt{\frac{\sum_{i=1}^{n}\left(Y_{i}-\hat{Y}_{i}\right)^{2}}{n}} \\
\mathrm{MPB}=100 \times \frac{\sum_{i=1}^{n}\left|Y_{i}-\hat{Y}_{i}\right|}{\sum_{i=1}^{n} Y_{i}}
\end{array}
$$

where, $Y_{i}$ and $\hat{Y}_{i}$ are actual and predicted values of diameter inside bark or stem volume of $i$ th observation ( $i$ th observation of diameter measurement or $i$ th individual tree for stem volume estimates), and $n$ is the total number of observations (number of diameter estimates or number of trees for stem volume estimates). For both dib and volume predictions, only the fixed effects were utilized. One alternative to selecting the "best" model based solely on its validation statistics is to compute the geometric mean of all predictions (W.T. Zakrzewski, personal communication). For comparison, the MAB, RMSE, and MPB were also calculated using this approach.

\subsection{Volume estimation}

Most taper equations used in this study either do not have corresponding closed-form volume equations or their integrated volume equations are difficult to derive and calculate. In order to obtain an estimated volume for each individual tree, we divided each tree into 100 sections. Smalian's formula was then used to calculate the volume for each section, and the summation of volumes of all sections resulted in the estimated individual tree volumes. Since most trees in our study had at least 10 observations per tree, a short interval between measurements, and observations were along the entire stem, the observed stem volumes were also derived through Smalian's formula. Using Smalian's formula to estimate tree volume has been reported many times in the literature (Corral-Rivas et al., 2007; Diéguez-Aranda et al., 2006; Hibbs et al., 2007; Maguire et al., 1998; Ozcelik, 2008; Zakrzewski, 1999; Zhang et al., 2002), although it may incur small bias on estimating the volumes of the stem tip.

Since it is widely used in the Acadian Region and most of our observations were from the same dataset, our predictions 
Table III. Absolute mean bias (MAB), root mean square error (RMSE) and mean percentage of bias (MPB) of diameter inside bark for balsam fir, red spruce, and white pine.

\begin{tabular}{|c|c|c|c|c|c|c|c|c|c|}
\hline \multirow{2}{*}{ Model } & \multicolumn{3}{|c|}{ Balsam fir } & \multicolumn{3}{|c|}{ Red spruce } & \multicolumn{3}{|c|}{ White pine } \\
\hline & MAB $(\mathrm{cm})$ & RMSE & MPB (\%) & MAB $(\mathrm{cm})$ & RMSE & MPB (\%) & MAB $(\mathrm{cm})$ & RMSE & MPB (\%) \\
\hline Max and Burkhart (1976) & 0.5319 & 0.8007 & 5.1889 & 0.5922 & 0.9294 & 5.5515 & 1.3647 & 1.9219 & 6.7420 \\
\hline Kozak (2004) Model 01 & 0.6883 & 0.9602 & 6.7140 & 0.8704 & 1.2052 & 8.1600 & 1.6792 & 2.2257 & 8.2959 \\
\hline Kozak (2004) Model 02 & 0.5042 & 0.7620 & 4.9184 & 0.5375 & 0.8179 & 5.0392 & 1.1564 & 1.6546 & 5.7128 \\
\hline Bi (2000) & 0.4954 & 0.7587 & 4.8322 & 0.5384 & 0.8254 & 5.0472 & 1.1937 & 1.7213 & 5.8971 \\
\hline Zakrzewski (1999) & 0.5104 & 0.7706 & 4.9787 & 0.6220 & 0.9363 & 5.8312 & 1.2974 & 1.9166 & 6.4095 \\
\hline Valentine and Gregoire (2001) & 0.4801 & 0.7443 & 4.6830 & 0.5725 & 0.8581 & 5.3667 & 1.2800 & 1.8112 & 6.3235 \\
\hline Sharma and Zhang (2004) & 0.5403 & 0.8120 & 5.2703 & 0.6292 & 0.9649 & 5.8982 & 1.3195 & 1.8292 & 6.5189 \\
\hline Sharma and Parton (2009) & 0.5437 & 0.8497 & 5.3040 & 0.6245 & 1.0120 & 5.8544 & 1.3342 & 1.8863 & 6.5914 \\
\hline Clark et al. (1991) I & 0.5229 & 0.7505 & 5.1003 & 0.5809 & 0.8517 & 5.4454 & 1.4205 & 2.0432 & 7.0176 \\
\hline Clark et al. (1991) II & 0.6417 & 0.8730 & 6.2595 & 0.7216 & 0.9932 & 6.7647 & 1.6174 & 2.2108 & 7.9907 \\
\hline Fang et al. (2000) & 0.5521 & 0.8129 & 5.3852 & 0.6177 & 0.9283 & 5.7907 & 1.3454 & 1.8623 & 6.6469 \\
\hline Geometric mean & 0.4742 & 0.7196 & 4.6257 & 0.5269 & 0.8066 & 4.9393 & 1.1468 & 1.6315 & 5.6657 \\
\hline
\end{tabular}

Clark et al. (1991) I: upper stem diameters at $5.27 \mathrm{~m}$ were obtained by linear interpolation. Clark et al. (1991) II: upper stem diameters at $5.27 \mathrm{~m}$ were predicted based on the regression form presented in Clark et al. (1991).

were also compared to the Honer (1965) volume equations. The estimated parameter values of the Honer (1965) volume equation for balsam fir, red spruce and white pine were defined and specified as:

$$
V=\frac{D^{2}}{\alpha+\beta / H}
$$

$\alpha=2.139, \beta=301.634$ for balsam fir; $\alpha=1.226, \beta=$ 315.832 for red spruce; $\alpha=0.691, \beta=363.676$ for white pine.

\subsection{Influence of crown variables}

As previously stated, the influence of crown variables on taper models depends on species, the range of crown sizes in the fitting dataset, and the particular taper equation used. In the present study, we added each of the three crown variables, namely crown length, crown ratio and height to live crown base, into the best fitted model identified for each species. Comparisons were made between fitted models with and without crown variables in terms of the bias values for the stem diameter and volume predictions.

All statistical analysis were carried out in R using the nlme library (Pinherio and Bates, 2000).

\section{RESULTS}

\subsection{Diameter inside bark estimates}

MAB of most taper equations for balsam fir and red spruce generally ranged between 0.5 and $0.7 \mathrm{~cm}$, whereas MAB for white pine ranged between 1.1 to $1.7 \mathrm{~cm}$ (Tab. III). The Kozak (2004) Model 02 model performed the best for both red spruce and white pine trees (MAB: 0.538 , MPB: $5.039 \%$ for red spruce; MAB: 1.156 , MPB: 5.713 for white pine), while the Valentine and Gregoire (2001) and Bi (2000) equations both performed slightly better for balsam fir (MAB: 0.480, MPB: 4.683\%; MAB: 0.495, MPB: 4.832\%;). On this dataset, the most biased model across the species was the Kozak (2001) Model 01 equation (MAB: $0.688 \mathrm{~cm}$, MPB: $6.714 \%$ for balsam fir; MAB: $0.870 \mathrm{~cm}$, MPB: $8.160 \%$ for red spruce; MAB: $1.679 \mathrm{~cm}, \mathrm{MPB}: 8.296 \%$ for white pine). The equations of $\mathrm{Bi}$ (2000), Valentine and Gregoire (2001), and Clark et al. (1991) with observed upper stem diameters performed quite well in terms of MAB and MPB for all three species. The most stable taper equations (i.e. the smallest RMSE) were the Valentine and Gregoire (2001) for balsam fir and the Kozak (2004) Model 02 for both red spruce and white pine. The Kozak (2004) Model 01 equation exhibited the largest variability for all three species. Although white pine had MAB almost twice as large as the other two species, the MPB did not show a significant difference as all models had less than $9 \%$ bias for the three species. Results also show that using the regression form provided in Clark et al. (1991) to predict the upper diameter at $5.27 \mathrm{~m}$ largely increased the bias for estimating dibs, compared with using interpolation method to obtain the upper diameter values (over 20\% higher for both balsam fir and red spruce, $13 \%$ higher for white pine). Compared with the best taper equation, the geometric mean of estimated dibs from the ten taper equations further reduced the bias by $1.2 \%, 1.9 \%$ and $0.8 \%$ for balsam fir, red spruce and white pine respectively in terms of MAB when compared to the best performing equation. Residual plots of all fitted models are presented in Figures 3-5 for balsam fir, red spruce, and white pine, respectively.

\subsection{Stem volume estimates}

The performance rank of volume prediction among the ten taper equations showed a slightly different trend than the dib results. Although the Kozak (2004) Model 01 and Valentine and Gregoire (2001) equations still performed well, the Clark et al. (1991) equation with observed upper diameter values at $5.27 \mathrm{~m}$ superseded them with a significantly lower 
Table IV. Absolute mean bias (MAB), root mean square error (RMSE) and mean percentage of bias (MPB) of stem volume for balsam fir, red spruce, and white pine.

\begin{tabular}{|c|c|c|c|c|c|c|c|c|c|}
\hline \multirow{2}{*}{ Model } & \multicolumn{3}{|c|}{ Balsam fir } & \multicolumn{3}{|c|}{ Red spruce } & \multicolumn{3}{|c|}{ White pine } \\
\hline & $\operatorname{MAB}\left(\mathrm{m}^{3}\right)$ & RMSE & $\mathrm{MPB}(\%)$ & $\operatorname{MAB}\left(\mathrm{m}^{3}\right)$ & RMSE & MPB(\%) & $\operatorname{MAB}\left(\mathrm{m}^{3}\right)$ & RMSE & MPB(\%) \\
\hline Max and Burkhart (1976) & 0.0110 & 0.0243 & 8.1573 & 0.0115 & 0.0270 & 7.9398 & 0.0951 & 0.2091 & 10.9017 \\
\hline Kozak (2004) Model 01 & 0.0100 & 0.0189 & 7.3840 & 0.0098 & 0.0180 & 6.7521 & 0.0624 & 0.1037 & 7.1535 \\
\hline Kozak (2004) Model 02 & 0.0090 & 0.0171 & 6.6734 & 0.0087 & 0.0159 & 5.9555 & 0.0574 & 0.0996 & 6.5803 \\
\hline $\mathrm{Bi}(2000)$ & 0.0090 & 0.0172 & 6.6428 & 0.0092 & 0.0174 & 6.3123 & 0.0557 & 0.0997 & 6.3860 \\
\hline Zakrzewski (1999) & 0.0091 & 0.0173 & 6.7331 & 0.0100 & 0.0175 & 6.8875 & 0.0557 & 0.1003 & 6.3843 \\
\hline Valentine and Gregoire (2001) & 0.0085 & 0.0162 & 6.3062 & 0.0092 & 0.0185 & 6.3125 & 0.0649 & 0.1254 & 7.4402 \\
\hline Sharma and Zhang (2004) & 0.0104 & 0.0200 & 7.6699 & 0.0109 & 0.0231 & 7.5071 & 0.0723 & 0.1465 & 8.2871 \\
\hline Sharma and Parton (2009) & 0.0108 & 0.0238 & 7.9902 & 0.0118 & 0.0285 & 8.1418 & 0.0875 & 0.1895 & 10.0282 \\
\hline Clark et al. (1991) I & 0.0082 & 0.0147 & 6.0595 & 0.0070 & 0.0128 & 4.7888 & 0.0540 & 0.1025 & 6.1865 \\
\hline Clark et al. (1991) II & 0.0105 & 0.0200 & 7.7710 & 0.0110 & 0.0220 & 7.5495 & 0.0748 & 0.1516 & 8.5723 \\
\hline Fang and Bailey (2000) & 0.0091 & 0.0169 & 6.7673 & 0.0088 & 0.0158 & 6.0287 & 0.0577 & 0.0964 & 6.6159 \\
\hline Honer equation (1967) & 0.0099 & 0.0176 & 7.3374 & 0.0110 & 0.0231 & 7.5901 & 0.0855 & 0.1671 & 9.8005 \\
\hline Geometric mean & 0.0069 & 0.0137 & 5.1013 & 0.0079 & 0.0162 & 5.4171 & 0.0497 & 0.0848 & 5.6970 \\
\hline
\end{tabular}

Clark et al. (1991) I: upper stem diameters at $5.27 \mathrm{~m}$ were obtained by linear interpolation.

Clark et al. (1991) II: upper stem diameters at $5.27 \mathrm{~m}$ were predicted based on the regression form presented in Clark et al. (1991).

MAB, RMSE, and MPB for all three species (Tab. IV). The MAB values for the Clark et al. (1991) taper equation were $0.0082,0.0070$, and $0.0540 \mathrm{~m}^{3}$ for balsam fir, red spruce, and white pine, respectively. The second best equation varied across the species, which were the Valentine and Gregoire (2001), the Kozak (2004) Model 02 and Zakrzewski (1999) for balsam fir, red spruce, and white pine, respectively, in terms of MAB. The corresponding Honer (1965) volume equation produced biases of $0.0099,0.0110$, and $0.0855 \mathrm{~m}^{3}$ for balsam fir, red spruce, and white pine, respectively. The poorest performing taper equation for predicting stem volume on this dataset was the Max and Burkhart (1976) (MAB: $0.011 \mathrm{~m}^{3}$, MPB: $8.157 \%$ for balsam fir; MAB: $0.012 \mathrm{~m}^{3}$, MPB: $7.940 \%$ for red spruce; MAB: 0.095, MPB: $10.902 \%$ for white pine). In general, white pine trees exhibited more bias and larger variability in predicting stem volume than the other two species. In short, the best performing taper equation of Clark et al. (1991) reduced the stem volume RMSE by $16 \%, 45 \%$, and $39 \%$ when compared to the commonly used Honer (1965) volume equation for balsam fir, red spruce, and white pine, respectively. When observed upper stem diameter measurements were not available, the Fang et al. (2000) equation reduced the stem volume RMSE by $4 \%, 32 \%$, and $42 \%$ when compared to the Honer (1965) volume equation. On average, most taper equations had less than $8 \%$ bias. Similar as dib predictions, the geometric mean of estimated volumes from the ten taper equations further reduced the bias by $16 \%$ and $8 \%$ for balsam fir and white pine, but no improvement was observed for red spruce.

\subsection{Influence of crown variables}

The variable exponent taper equation Kozak (2004) Model 02, the segmented taper equation Clark et al. (1991), and the volume compatible taper equation Fang et al. (2000) were selected for evaluating the effects of the incorporation of additional crown variables. Crown ratio (CR), crown length (CL), and height to live crown base (HCB) variables were added into Kozak Model 02, Clark et al. (1991) and Fang et al. (2000) taper equations. Their corresponding mathematical equations were:

Kozak (2004) Model 02:

$$
d_{i}=\alpha_{0} D^{\alpha_{1}} H^{\alpha_{2}} X_{i}^{\beta_{1} z_{i}^{4}+\beta_{2}\left(\frac{1}{e^{D / H}}\right)+\beta_{3} X_{i}^{0.1}+\beta_{4}(1 / D)+\beta_{5} H^{Q_{i}}+\beta_{6} X_{i}+\beta_{7} \mathrm{CRWN}}
$$

Clark et al. (1991):

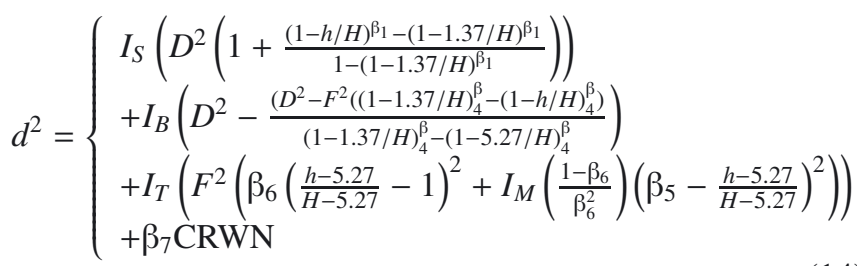

Fang et al. (2000):

$$
d=c_{1} \sqrt{H^{\left(k-\beta_{1}\right) / \beta_{1}}(1-z)^{(k-b) / b} q_{1}^{I_{1}+I_{2}} q_{2}^{I_{2}}}
$$

$c_{1}=\sqrt{\left(\alpha_{0}+\alpha_{3} \mathrm{CRWN}\right) D^{\alpha_{1}} H^{\alpha_{2}-k / \beta_{1}} /\left(\beta_{1}\left(t_{0}-t_{1}\right)+\beta_{2}\left(t_{1}-q_{1} t_{2}\right)+\beta_{3} q_{1} t_{2}\right)}$

where CRWN is the crown variable, which represented either $\mathrm{CR}, \mathrm{CL}$, or $\mathrm{HCB}$, and $\beta_{7}$ and $a_{3}$ are the parameters related to this crown variable that needs to be estimated. All other notation is the same as defined previously.

For the dib prediction, all three crown variables had positive effects in the Kozak (2004) Model 02 across the species, except for HCB in white pine (Tab. V). The addition of CR improved the model performance the most for balsam fir and red spruce trees by reducing MAB $2.2 \%$ and $2.5 \%$ respectively.

The effects of crown variables in the Clark et al. (1991) equation were mixed across species. For the Clark equation using interpolated upper diameter values at $5.27 \mathrm{~m}, \mathrm{CR}$ had 
Table V. Absolute mean bias (MAB), root mean square error (RMSE) and mean percentage of bias (MPB) of diameter inside bark with and without crown variables for balsam fir, red spruce, and white pine.

\begin{tabular}{|c|c|c|c|c|c|c|c|c|c|}
\hline \multirow{2}{*}{ Model } & \multicolumn{3}{|c|}{ Balsam fir } & \multicolumn{3}{|c|}{ Red spruce } & \multicolumn{3}{|c|}{ White pine } \\
\hline & MAB $(\mathrm{cm})$ & RMSE & MPB (\%) & MAB $(\mathrm{cm})$ & RMSE & MPB (\%) & MAB $(\mathrm{cm})$ & RMSE & MPB (\%) \\
\hline Kozak (2004) Model 02 without Crown & 0.5042 & 0.7620 & 4.9184 & 0.5375 & 0.8179 & 5.0392 & 1.1564 & 1.6546 & 5.7128 \\
\hline Kozak (2004) Model 02 with CR & 0.4933 & 0.7402 & 4.8115 & 0.5242 & 0.7959 & 4.9143 & 1.1548 & 1.6514 & 5.7050 \\
\hline Kozak (2004) Model 02 with CL & 0.4982 & 0.7481 & 4.8593 & 0.5269 & 0.7992 & 4.9395 & 1.1571 & 1.6528 & 5.7162 \\
\hline Kozak (2004) Model 02 with HCB & 0.4966 & 0.7460 & 4.8440 & 0.5317 & 0.8066 & 4.9843 & 1.1535 & 1.6534 & 5.6988 \\
\hline Clark et al. (1991) I without Crown & 0.5229 & 0.7505 & 5.1003 & 0.5809 & 0.8517 & 5.4454 & 1.4205 & 2.0432 & 7.0176 \\
\hline Clark et al. (1991) I with CR & 0.5003 & 0.7214 & 4.8806 & 0.5676 & 0.8106 & 5.3211 & 1.4024 & 2.0221 & 6.9281 \\
\hline Clark et al. (1991) I with CL & 0.5042 & 0.7253 & 4.9182 & 0.5678 & 0.8126 & 5.3225 & 1.4587 & 2.0952 & 7.2062 \\
\hline Clark et al. (1991) I with HCB & 0.5178 & 0.7428 & 5.0511 & 0.5953 & 0.8455 & 5.5805 & 1.5344 & 2.1777 & 7.5804 \\
\hline Clark et al. (1991) II without crown & 0.6417 & 0.8730 & 6.2595 & 0.7216 & 0.9932 & 6.7647 & 1.6174 & 2.2108 & 7.9907 \\
\hline Clark et al. (1991) II with CR & 0.6291 & 0.8595 & 6.1362 & 0.7060 & 0.9683 & 6.6187 & 1.6203 & 2.2154 & 8.0046 \\
\hline Clark et al. (1991) II with CL & 0.6335 & 0.8628 & 6.1796 & 0.7105 & 0.9709 & 6.6608 & 1.6539 & 2.2745 & 8.1710 \\
\hline Clark et al. (1991) II with HCB & 0.6459 & 0.8791 & 6.3003 & 0.7410 & 1.0066 & 6.9464 & 1.7006 & 2.3484 & 8.4015 \\
\hline Fang et al. (2000) without crown & 0.5521 & 0.8129 & 5.3852 & 0.6177 & 0.9283 & 5.7907 & 1.3454 & 1.8623 & 6.6469 \\
\hline Fang et al. (2000) with CR & 0.7578 & 1.0078 & 7.3920 & 0.6888 & 1.0042 & 6.4575 & 1.3737 & 1.9041 & 6.7866 \\
\hline Fang et al. (2000) with CL & 0.6431 & 0.9250 & 6.2733 & 0.6582 & 0.9835 & 6.1706 & 1.3783 & 1.9083 & 6.8092 \\
\hline Fang et al. (2000) with HCB & 0.9925 & 1.2837 & 9.6810 & 0.7800 & 1.0935 & 7.3125 & 1.3246 & 1.8350 & 6.5437 \\
\hline
\end{tabular}

CR: Crown ratio. CL: Crown length. HCB: Height to live crown base.

Clark et al. (1991) I: upper stem diameters at $5.27 \mathrm{~m}$ were obtained by linear interpolation.

Clark et al. (1991) II: upper stem diameters at $5.27 \mathrm{~m}$ were predicted based on the regression form presented in Clark et al. (1991).

Table VI. Absolute mean bias (MAB), root mean square error (RMSE) and mean percentage of bias (MPB) of stem volume with and without crown variables for balsam fir, red spruce, and white pine.

\begin{tabular}{|c|c|c|c|c|c|c|c|c|c|}
\hline \multirow{2}{*}{ Model } & \multicolumn{3}{|c|}{ Balsam fir } & \multicolumn{3}{|c|}{ Red spruce } & \multicolumn{3}{|c|}{ White pine } \\
\hline & $\operatorname{MAB}\left(\mathrm{m}^{3}\right)$ & RMSE & MPB (\%) & $\operatorname{MAB}\left(\mathrm{m}^{3}\right)$ & RMSE & MPB (\%) & $\operatorname{MAB}\left(\mathrm{m}^{3}\right)$ & RMSE & MPB (\%) \\
\hline Kozak (2004) Model 02 without crown & 0.0090 & 0.0171 & 6.6734 & 0.0087 & 0.0159 & 5.9555 & 0.0574 & 0.0996 & 6.5803 \\
\hline Kozak (2004) Model 02 with CR & 0.0085 & 0.0156 & 6.2899 & 0.0086 & 0.0161 & 5.8985 & 0.0587 & 0.1014 & 6.7258 \\
\hline Kozak (2004) Model 02 with CL & 0.0085 & 0.0156 & 6.3153 & 0.0086 & 0.0161 & 5.9332 & 0.0582 & 0.1008 & 6.6668 \\
\hline Kozak (2004) Model 02 with HCB & 0.0087 & 0.0165 & 6.4656 & 0.0086 & 0.0163 & 5.9139 & 0.0583 & 0.1014 & 6.6838 \\
\hline Clark et al. (1991) I without Crown & 0.0082 & 0.0147 & 6.0595 & 0.0070 & 0.0128 & 4.7888 & 0.0540 & 0.1025 & 6.1865 \\
\hline Clark et al. (1991) I with CR & 0.0070 & 0.0131 & 5.1463 & 0.0065 & 0.0109 & 4.4702 & 0.0469 & 0.0924 & 5.3738 \\
\hline Clark et al. (1991) I with CL & 0.0070 & 0.0129 & 5.1798 & 0.0068 & 0.0115 & 4.6791 & 0.0541 & 0.1015 & 6.2023 \\
\hline Clark et al. (1991) I with HCB & 0.0078 & 0.0143 & 5.7969 & 0.0079 & 0.0130 & 5.4126 & 0.0641 & 0.1125 & 7.3535 \\
\hline Clark et al. (1991) II without crown & 0.0105 & 0.0200 & 7.7710 & 0.0110 & 0.0220 & 7.5495 & 0.0748 & 0.1516 & 8.5723 \\
\hline Clark et al. (1991) II with CR & 0.0098 & 0.0188 & 7.2301 & 0.0108 & 0.0198 & 7.4272 & 0.0731 & 0.1477 & 8.3773 \\
\hline Clark et al. (1991) II with CL & 0.0098 & 0.0187 & 7.2870 & 0.0109 & 0.0195 & 7.4755 & 0.0781 & 0.1576 & 8.9493 \\
\hline Clark et al. (1991) II with HCB & 0.0106 & 0.0201 & 7.8187 & 0.0119 & 0.0215 & 8.2216 & 0.0856 & 0.1696 & 9.8180 \\
\hline Fang et al. (2000) without crown & 0.0091 & 0.0169 & 6.7673 & 0.0088 & 0.0158 & 6.0287 & 0.0577 & 0.0964 & 6.6159 \\
\hline Fang et al. (2000) with CR & 0.0086 & 0.0153 & 6.3329 & 0.0086 & 0.0154 & 5.8940 & 0.0576 & 0.0963 & 6.6065 \\
\hline Fang et al. (2000) with CL & 0.0084 & 0.0151 & 6.1996 & 0.0085 & 0.0154 & 5.8388 & 0.0577 & 0.0963 & 6.6145 \\
\hline Fang et al. (2000) with HCB & 0.0086 & 0.0153 & 6.3526 & 0.0086 & 0.0155 & 5.9427 & 0.0576 & 0.0963 & 6.6057 \\
\hline
\end{tabular}

CR: Crown ratio. CL: Crown length. HCB: Height to live crown base.

Clark et al. (1991) I: upper stem diameters at $5.27 \mathrm{~m}$ were obtained by linear interpolation.

Clark et al. (1991) II: upper stem diameters at $5.27 \mathrm{~m}$ were predicted based on the regression form presented in Clark et al. (1991).

a positive effect across the three species, $\mathrm{CL}$ also had a positive effect for balsam fir and red spruce, while HCB only improved the model performance for balsam fir. For the Clark et al. (1991) equation using predicted upper diameter values at $5.27 \mathrm{~m}$, the addition of crown variables had similar effects on the model performance. Both CR and CL variables improved the model performance for balsam fir and red spruce. The largest improvement in dib prediction in the Clark et al. (1991) equation was due to the inclusion of CR for balsam fir, where the MAB was decreased by $0.023 \mathrm{~cm}$ and the value of
RMSE was reduced by $0.03 \mathrm{~cm}$. However, all the improvements were very small. The effects of crown variables in the Fang et al. (2000) equation were mostly negative as all three crown variables increased the biases for all three species, except for HCB variable for white pine, which only slightly improved the model performance.

For the stem volume prediction, significant improvements were observed in the Clark et al. (1991) equation using interpolated upper diameters due to the inclusion of the CR variable for balsam fir (14.6\%), red spruce (7.1\%), and white pine 
(13.1\%) (Tab. VI). In the Kozak (2004) Model 02 equation, both CR and CL variables reduced the bias by $5.5 \%$ for balsam fir. Modest improvements were also produced for red spruce with the addition of the $\mathrm{CL}$ and $\mathrm{HCB}$ variables in both equations of the Kozak (2004) Model 02 and Clark et al. (1991) with predicted upper diameters. However, white pine showed very little sensitivity to crown variables in both equations. In the Fang et al. (2000) equation, CR reduced the bias by $7.7 \%$ for balsam fir. Other modest improvements were also observed with the addition of crown variables for red spruce and white pine.

\section{DISCUSSION}

Taper equations are invaluable tools, but selecting an appropriate model that works well across multiple species and various stand conditions can be difficult because of the variety of forms that are currently available. In this study, an extensive regional database for three ecologically distinct conifer species was compiled and used to compare ten commonly used taper equations. Across the species, the variable-exponent taper equation of Kozak (2004) Model 02 and the segmented taper equation of Clark et al. (1991) were identified as the most reliable and accurate taper equations for predicting both dib and total stem volume, respectively. The Valentine and Gregoire (2001) taper equation, which includes HCB as an input variable, performed well for balsam fir in stem form and volume predictions. The inclusion of crown variables such as crown ratio and crown length only slightly improved stem form predictions, despite the large range of crown sizes available in this analysis. However, inclusion of crown ratio largely improved stem volume predictions for balsam fir and red spruce. Compared with the widely used Honer (1965) regional volume equation, most taper equations in our study have a better predictive ability for estimating individual tree stem volume.

The Kozak (2004) Model 02 equation has previously been shown to work well across a range of species and biogeoclimatic zones. In maritime pine in Spain, Rojo et al. (2005) also found that the Kozak (2004) Model 02 had the lowest mean square error (MSE) of 31 different taper equations for predicting dob and its MSE was $4.5 \%$ lower than the next best performing equation. The Clark et al. (1991) taper equation was also developed to work well across multiple species as it was originally applied to 58 different tree species in the Southern US. In comparison to the Max and Burkhart (1976) equation, Jiang et al. (2005) found the Clark et al. (1991) reduced the standard error of estimate by 16 to $23 \%$ in predicting dob and dib of yellow-poplar. In predicting dib in this present study, the best equation depended on species, as the Kozak (2004) Model 02 equation had a RMSE that was lower than the next best performing equation for red spruce and white pine, respectively. For balsam fir, the Kozak (2004) Model 02 and Valentine and Gregoire (2001) equations performed equally well as the difference in RMSE was less than $2.3 \%$. This suggests that variable exponent equations like the Kozak (2004) Model 02 may have greater flexibility and ease in representing variation in stem form than significantly more complex equations. In addition, the Kozak (2004) Model 02 equation pro- vided a smooth continuous taper profile for each tree, while other taper equations such as Valentine and Gregoire (2001), and Clark et al. (1991) equations described the tree shape in three segmented sections.

A taper equation not only needs to predict stem form well, but also provide accurate estimates of stem volume. A relatively limited number of studies have compared the accuracy of stem taper equations in predicting actual stem volume because of the difficulty in measuring the true stem volume. Filho and Schaaf (1999) indicated that the Clark et al. (1991) equation was the best at estimating true stem volume (determined with a xylometer) of the models examined in their study. Most studies must obtain observed stem volume by using either Smalian or Huber's formula, which often leads to an underestimation of a taper equation's true error (e.g. Filho and Schaaf 1999). Although Smalian's formula can be highly biased, its use in this study was believed justified as the distance between observations was taken along the full length of the stem and generally they were less than $2 \mathrm{~m}$ apart. The numerical integration of natural cubic splines for each individual tree volume were also tested and the difference between Smalian's and the derived splines were less than $1 \%$ of the average tree volume. Thus, the results of this study further suggest that the Clark et al. (1991) equation was significantly superior across multiple species at estimating volume when upper stem diameter measurements are available, which supports the results of several other studies (e.g. Filho and Schaaf 1999; Jiang et al. 2005). In this present study, the Clark et al. (1991) equation reduced the RMSE by 9.3 , and $19.5 \%$ when compared to the next best equation for balsam fir and red spruce, respectively. For white pine, the Clark et al. (1991) equation still gave the best predictions of stem volume, but its RMSE was slightly poorer than that of $\mathrm{Bi}$ (2000), Zakrzewski (1999), Kozak (2004) Model 02 and Fang et al. (2000). Clearly, the segmented form-class approach of Clark et al. (1991) excels at estimating stem volume. Further, it does not require numerical integration like the variable exponent equations. However, the accuracy of predicting upper diameters at $5.27 \mathrm{~m}$ was important in determining the model's performance, as there was a significant difference in the model performance when observed versus predicted upper diameters were used. When measurements at $5.27 \mathrm{~m}$ are not available, other well-behaved taper equations should be considered. In our study, the Valentine and Gregoire (2001), Kozak (2004) Model 02 and Bi (2000) all performed well depending on species.

Compatible taper and volume equations offer several benefits such as additivity and flexibility over traditional taper equations (Fang et al., 2000). Diéguez-Aranda et al. (2006) compared 15 different compatible taper equations for Scots pine [Pinus sylvestris (L.)] and found the compatible taper/volume system of Fang et al. (2000) provided the best overall performance in estimating total stem volume, while its prediction of stem form was similar to those provided by a continuous variable form equation. A similar result was recently found by Corral-Rivas (2007) for five major pine species in Durango, Mexico. Although comparing the merits of compatible and traditional taper equations was not an explicit objective of this present analysis, we did find the Fang 
Table VII. Estimated parameters and standard errors of the best two models for balsam fir, red spruce, and white pine.

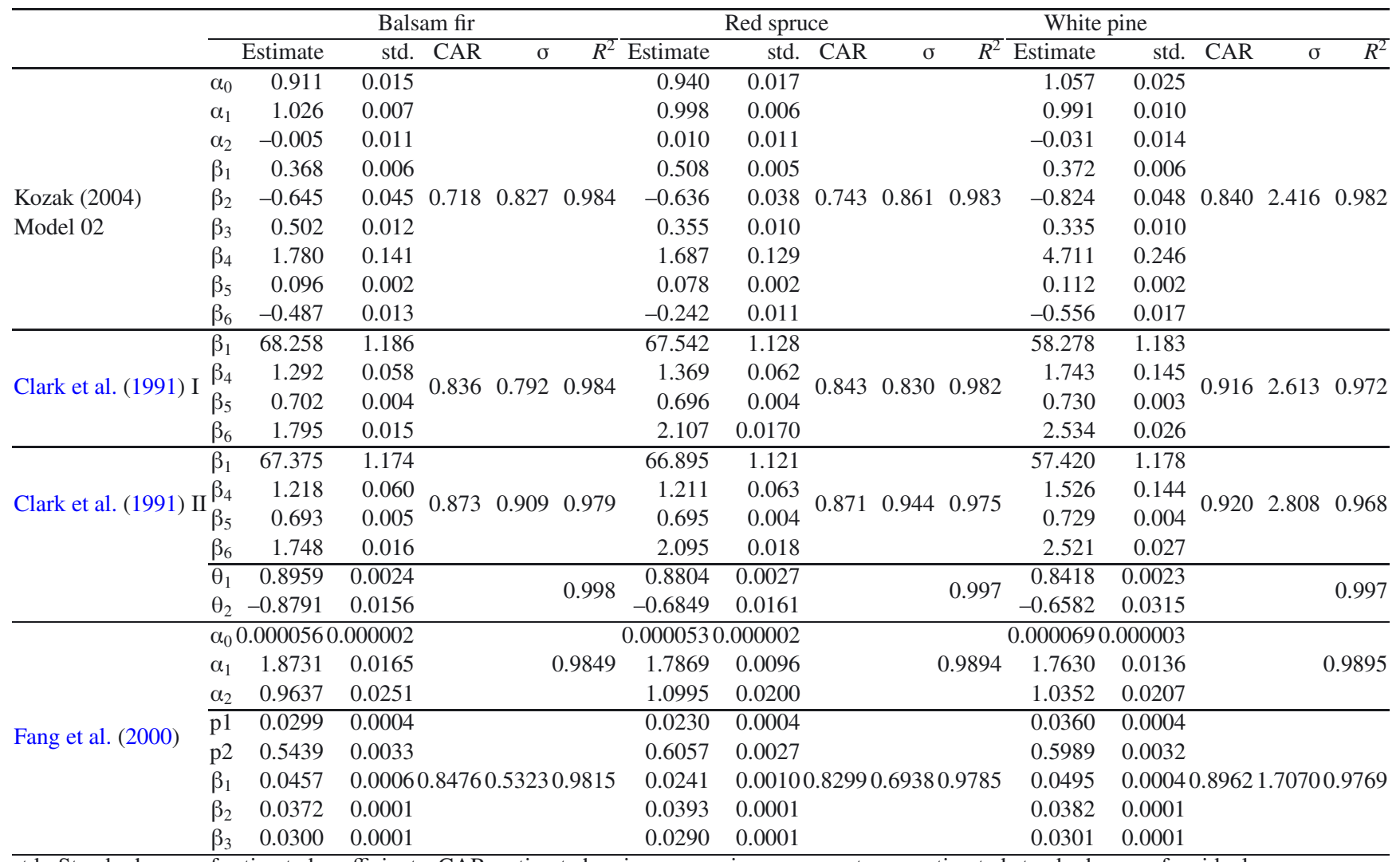

std.: Standard error of estimated coefficients, CAR: estimated variance-covariance parameter, $\sigma$ : estimated standard error of residuals.

Clark et al. (1991) I: upper stem diameters at $5.27 \mathrm{~m}$ were obtained by linear interpolation.

Clark et al. (1991) II: upper stem diameters at $5.27 \mathrm{~m}$ were predicted based on the regression form presented in Clark et al. (1991).

et al. (2000) equation performed well in estimating total stem volume, but its RMSE for volume was similar and in some cases, slightly worse than those of the non-compatible taper equations. Interestingly, the Fang et al. (2000) equation has primarily been used for Pinus species and the equation performed best in predicting white pine stem volume in our analysis. However, other models were generally superior to the Fang et al. (2000) for predicting stem form, which suggests there are some trade-offs to ensuring compatibility and need to be considered when selecting an appropriate model. As mentioned above, one alternative to selecting the "best" taper equation is to use the geometric mean of all predictions (W.T. Zakrzewski, personal communication). For both stem form and stem volume predictions, this method provided the best predictions relative to the performance of any given equation. This indicates that this may be a viable option when multiple taper equations exist for a given species and reduces the difficulty of selecting the "best" equation, which is usually dataset dependent.

The past literature suggests that the ability of crown variables to improve the performance of taper equations is speciesspecific and possibly, study-specific too. The level of improvement is likely a function of natural variation in crown dimensions, the range of crown sizes represented by a given dataset, and the sensitivity of particular model form to additional co- variates. Over the entire stem, Leites and Robinson (2004) in loblolly pine found that crown variables improved by average absolute difference in predicting dib by nearly $6 \%$ when compared to the next best equation. In a hardwood species, Jiang et al. (2005) found that dob and dib predictions were improved by 0.5 to $4.1 \%$ with the inclusion of crown variables in a taper equation for yellow-poplar, while cubic volume predictions were only improved by $<0.1$ to slightly over $1 \%$. Given the range of stand conditions and crown sizes examined in our analysis, the addition of crown variables was expected to perform well. We observed a substantial reduction of the bias in stem volume predictions for balsam fir with the inclusion of crown ratio and crown length. In addition, crown variables improved the RMSE of dib and stem volume predictions by 3.9 and $10.9 \%$ for balsam fir, 4.8 and $14.8 \%$ for red spruce, and 1.0 and $9.9 \%$ for white pine, respectively. It should be noted that these improvements were generally observed using the Clark et al. (1991) rather than the Kozak (2004) Model 02 equation. Several other researchers have noted improvements in stem form and volume predictions with the inclusion of crown variables, particularly for several other Pinus spp. such as loblolly pine (Valenti and Cao, 1986), lodgepole pine (Muhairwe et al. 1994), shortleaf pine [Pinus echinata Mill.] (Farrar and Murphy, 1987), and longleaf pine [Pinus 

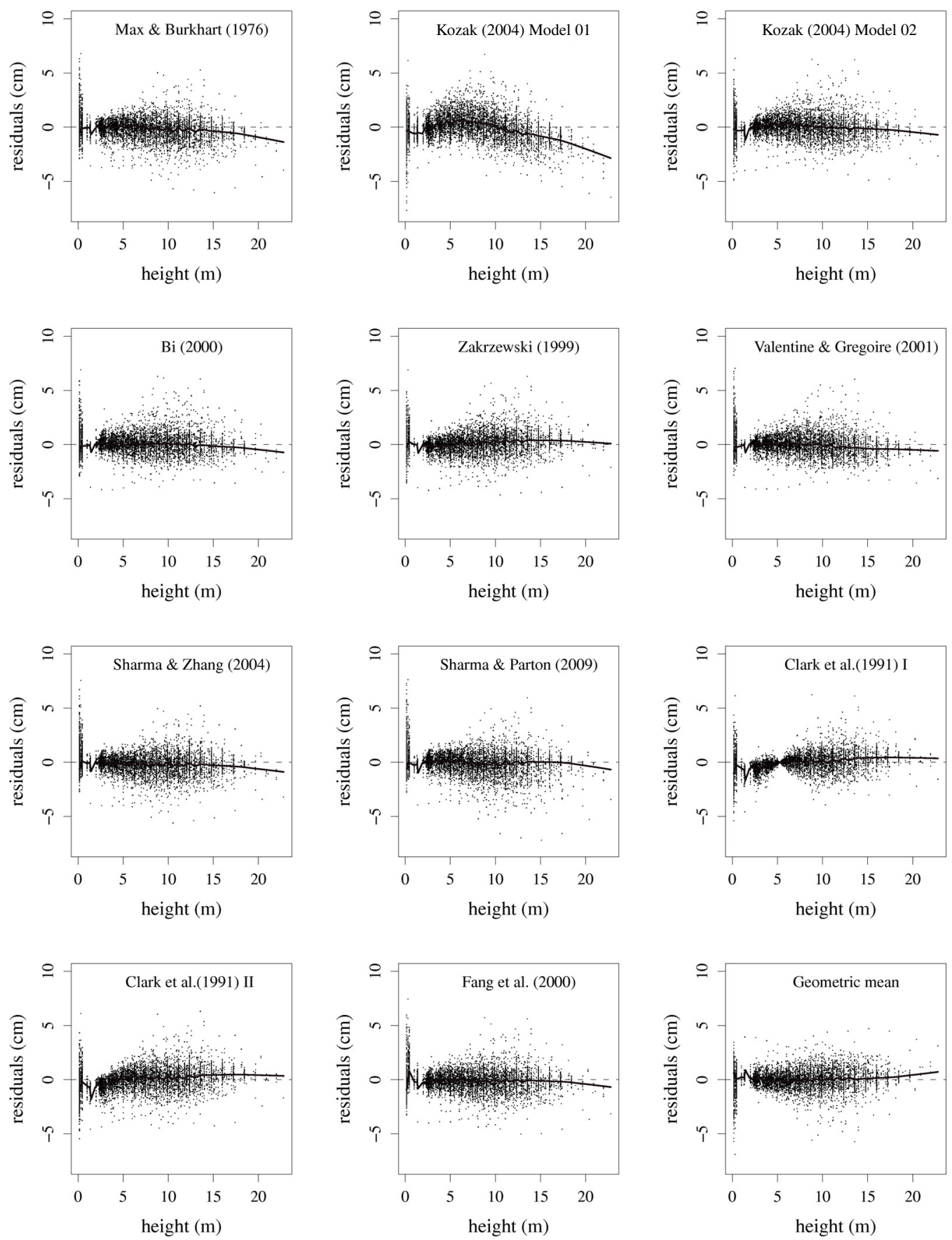

Figure 3. Residual plots (observed-predicted) of fitted models of diameter inside bark for balsam fir. Solid line is a lowess regression.

palustris Mill.] (Shaw et al., 2003). The results of this study indicated modest gains of stem form and relatively large gains of stem volume for the most shade tolerant and intolerant species examined in this analysis, which suggests that shade tolerance might be the driving factor for the importance of crown variables in taper equations. The results of Walters and Hann (1986) also indicated that crown ratio significantly improved predictions of stem form across a wide range of species shade tolerance levels in mixed conifer stands of southwest Oregon. Hence, model form and study species are likely confounding the interpretation of the importance of crown variable in taper equations and an analysis utilizing a similar model form across a wider range of species than this present study would be a better test of this hypothesis. 

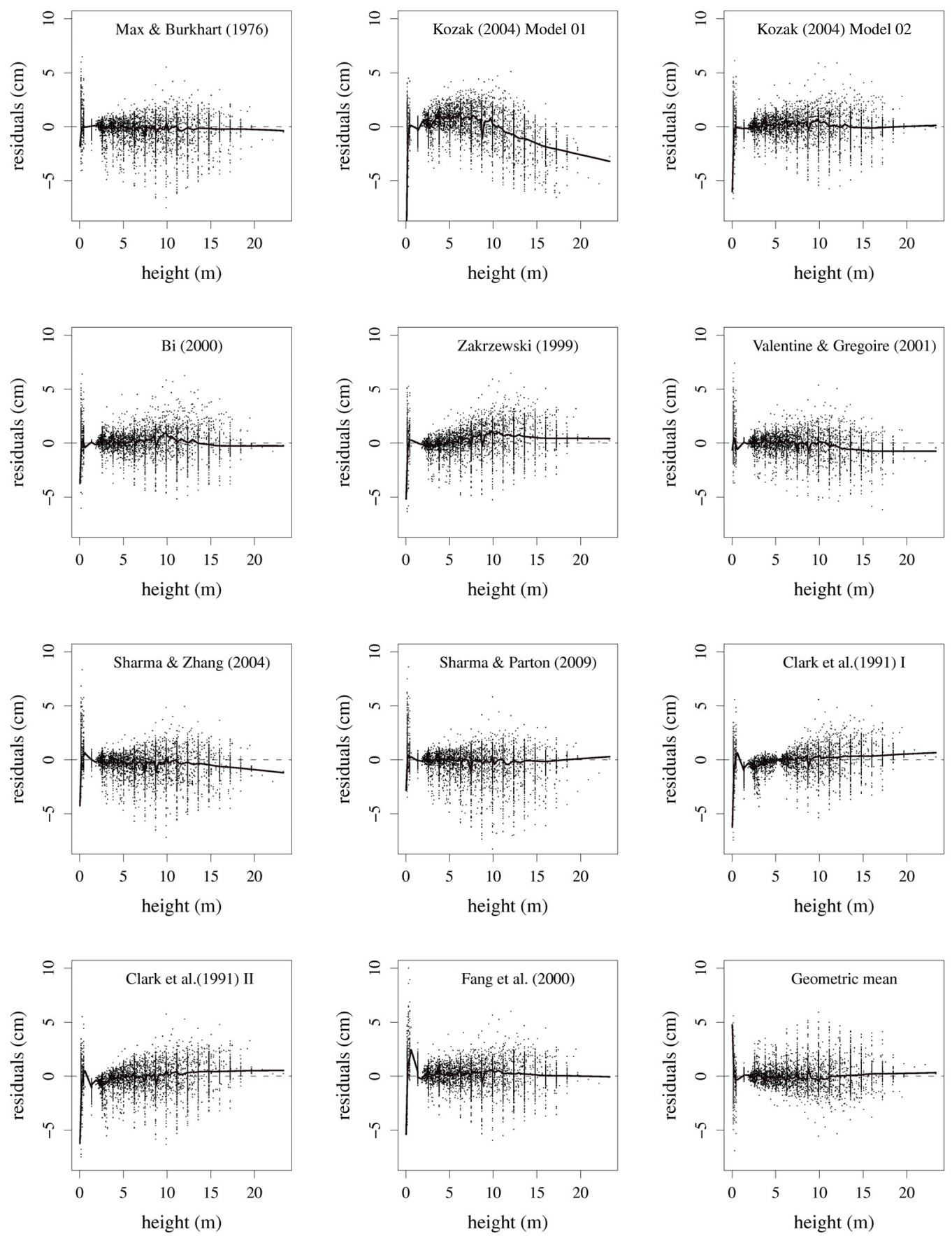

Figure 4. Residual plots (observed-predicted) of fitted models of diameter inside bark for red spruce. Solid line is a lowess regression.

White pine trees showed a slightly different trend from the other two species in our study (e.g. higher between-tree variation and greater bias in the final equation). A portion of this difference can be easily attributed to the greater range of tree sizes available in the white pine dataset in comparison to the other two species (e.g. Figs. 1, 2 and Tab. I). White pine may also have higher inherent between-tree variation because of the long-term impacts of white pine weevil [Pissodes strobi
(Peck)] in this region, which can cause extensive damage to the leader and severe stem deformities. Although severely damaged stems were not utilized in this study, a high proportion of white pines in the eastern US are impacted by the weevil to some degree and consequently, subtle changes in the stem form can not entirely accounted for by tree size. For a given tree size, white pine showed larger inter-tree variation and higher residual standard errors for all examined equations 

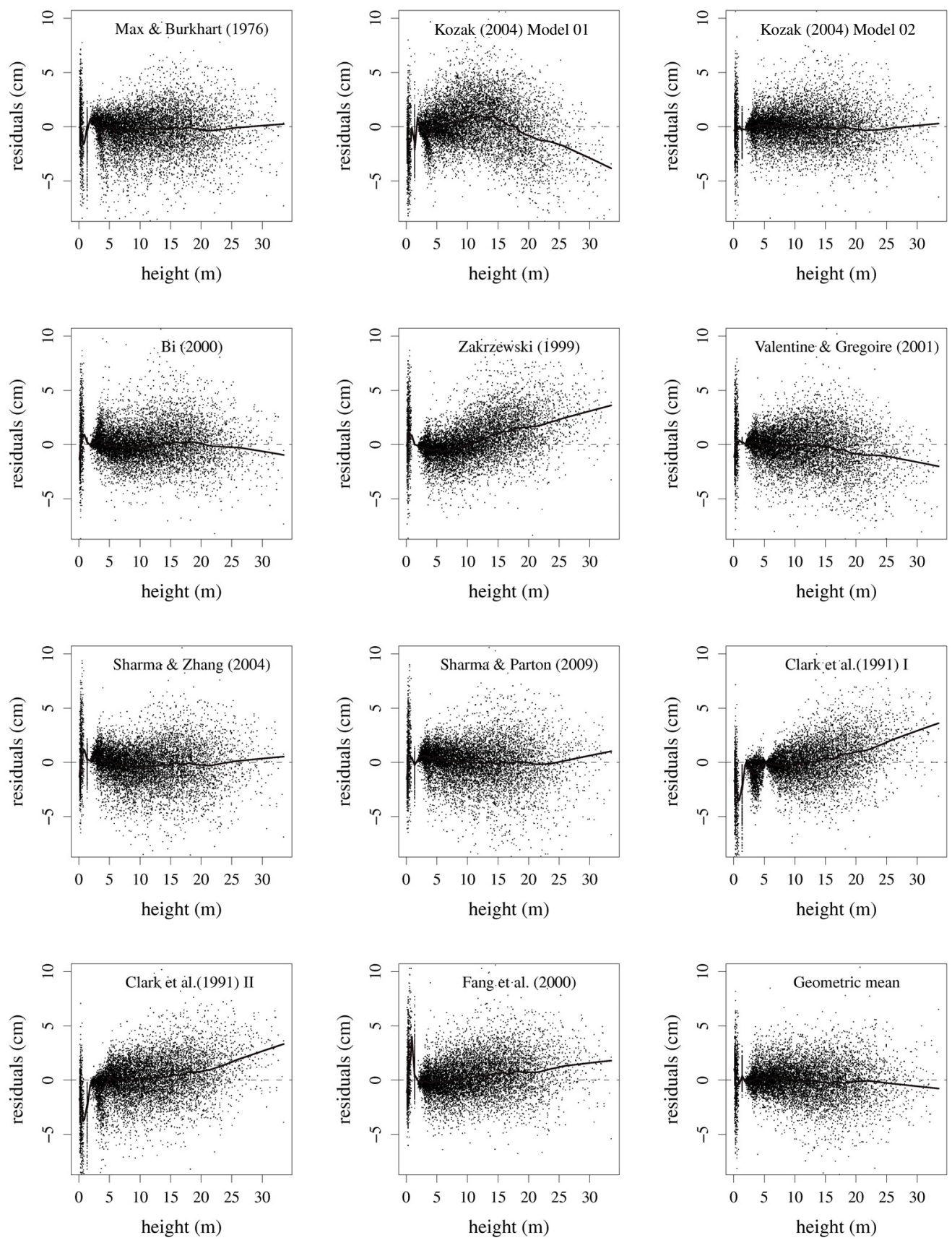

Figure 5. Residual plots (observed-predicted) of fitted models of diameter inside bark for white pine. Solid line is a lowess regression.

than the other two species (Tab. VII). However, for a tree with the same size (i.e. same DBH and total height), the taper profile of three species did not differ greatly, with the predicted lower section almost identical among three species (Fig. 6). The difference existed in the upper- and mid-portions of the stem, where red spruce was predicted to have a greater relative diameter in the Kozak (2004) Model 02, and white pine showed a greater relative diameter in the Clark et al. (1991) equation in comparison to the other species.

\section{CONCLUSIONS}

This analysis represents one of the first attempts to develop a regional taper equation for the primary conifer species in the Acadian Region of North America. Of the ten taper equations evaluated, the Clark et al. (1991) equation proved to be the best at predicting stem volume across the three species when upper stem diameter measurements are available. The Kozak (2004) Model 02 was the most accurate equation for 

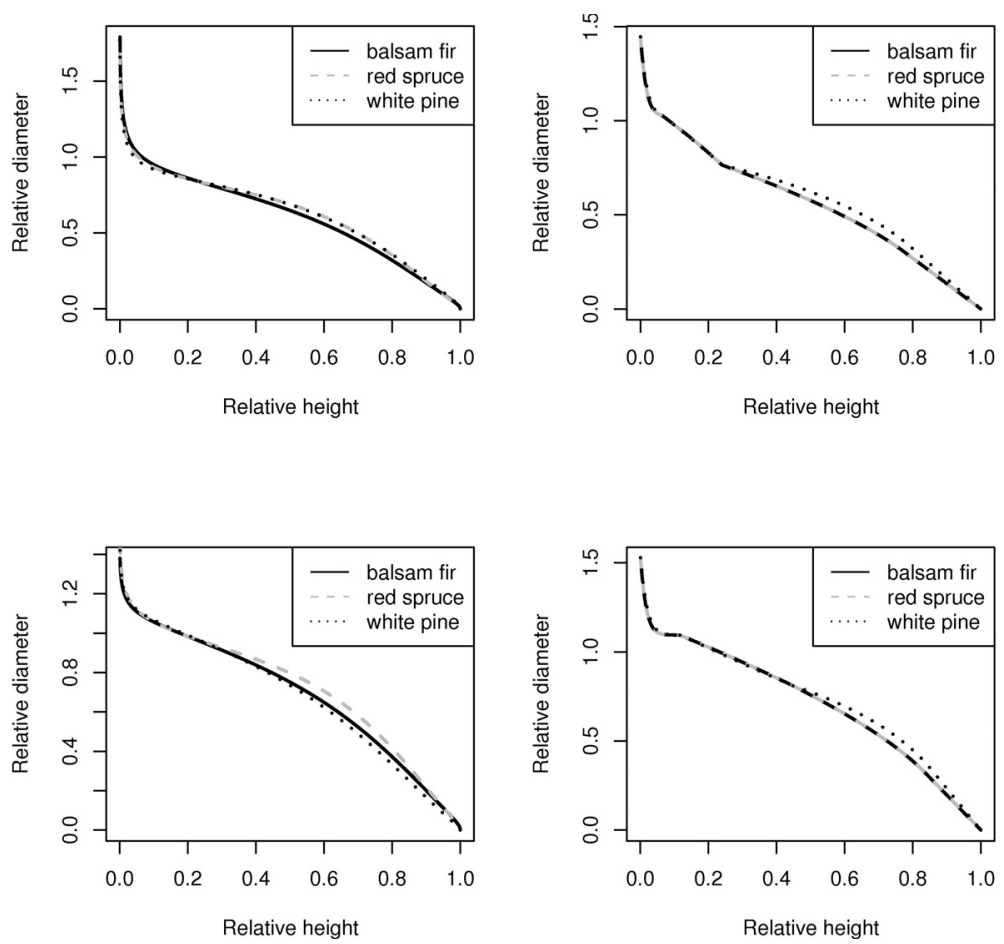

Figure 6. Predicted relative diameter over relative height using the Kozak (2004) Model 02 (left) and Clark et al. (1991) (right) taper equations for a large tree (upper; total height: $22 \mathrm{~m}, \mathrm{DBH}: 35 \mathrm{~cm}$ ) and a small tree (bottom; total height: $11.8 \mathrm{~m}, \mathrm{DBH}$ : $11.6 \mathrm{~cm}$ ).

predicting red spruce and white pine stem form. The inclusion of additional crown variable generally had a minimal impact on improving predictions of either stem form or volume for the Kozak (2004) Model 02. Modest improvements in the Clark et al. (1991) equation were observed for red spruce and white pine. Compared to the Honer (1965) stem volume equations, these taper equations are a vast improvement with reductions in the prediction error upwards to $45 \%$. However, selecting the "best" equation is difficult as it depends on species, dataset, and intended use. The use of the geometric mean of all predictions is, therefore, suggested when multiple equations for a certain species exist. The equations performed well across a range of stand conditions and will likely help improve estimates of standing volume in the region.

Acknowledgements: This study was supported by the University of Maine Forest Bioproducts Research Initiative, Cooperative Forestry Research Unit, and School of Forest Resources. Our thanks also goes to Ontario Ministry of Natural Resources, Robert Seymour, Laura Kenefic, Leah Phillips, Dan Gilmore, Doug Maguire, Micah Pace, Spencer Meyer, and Bret Vicary for providing access to the data used in this analysis. Special thanks to Jeff Gove, Dan Binkley, Voyteck Zakrzewski, and two anonymous reviewers who helped to improve an earlier draft of this manuscript.

\section{REFERENCES}

Bi H., 2000. Trigonometric variable-form taper equations for Australian eucalyptus. For. Sci. 46: 397-409.
Briggs R.D. and Lemin R.C., Jr., 1992. Delineation of climatic regions in Maine. Can. J. For. Res. 22: 801-811.

Burkhart H.E. and Walton S.B., 1985. Incorporating crown ratio into taper equations for loblolly pine trees. For. Sci. 31: 478-484.

Chi E.M. and Reinsel G.C., 1989. Models for longitudinal data with random effects and AR(1) errors. J. Amer. Statistical Assoc. 84: 452460 .

Clark III A.C., Souter R.A., and Schlaegel B.E., 1991. Stem profile equations for southern tree species. USDA For. Serv. South. Res. Pap. SE-282. Asheville, NC. 113 p.

Clutter J.L., Fortson J.C., Pienaar L.V., Brister G.H., and Bailey R.L., 1983. Timber Management, John Wiley \& Sons.

Corral-Rivas J.J., Diéguez-Aranda U., Rivas S.C., and Dorado F.C., 2007. A merchantable volume system for major pine species in El Salto, Durango (Mexico). For. Ecol. Manage. 238: 118-129.

Diéguez-Aranda U., Castedo-Dorado F., Álvarez-González J.G., and Rojo A., 2006. Compatible taper function for plantations in northwestern Spain. Can. J. For. Res. 36: 1190-1205.

Davidian M. and Giltinan D.M., 1995. Nonlinear models for repeated measurement data. Chapman \& Hall.

Fang Z., Borders B.E., and Bailey R.L., 2000. Compatible volume-taper models for loblolly and slash pine based on a system with segmentedstem form factors. For. Sci. 46: 1-12.

Farrar R.M. and Murphy P.A., 1987. Taper functions for predicting product volumes in natural shortleaf pine. US For. Serv. Res. Pap. SO234, Asheville, NC, 9 p.

Filho A.F. and Schaaf L.B., 1999. Comparison between predicted volumes estimated by taper equations and true volumes obtained by the water displacement technique (xylometer). Can. J. For. Res. 29: 451461. 
Garber S.M. and Maguire D.A., 2003. Modeling stem taper of three central Oregon species using nonlinear mixed effects models and autoregressive error structures. For. Ecol. Manage. 179: 507-522.

Gilmore D.W. and Seymour R.S., 1996. Alternative measures of stem growth efficiency applied to Abies balsamea from four canopy positions in central Maine. For. Ecol. Manage. 84: 209-218.

Gregoire T.G., Schabenberger O., and Barrett J.P., 1995. Linear modelling of irregularly spaced, unbalanced, longitudinal data from permanent-plot measurements. Can. J. For. Res. 25: 137-156.

Hibbs D.E., Bluhm A.R., and Garber S.M., 2007. Stem taper and volume of managed red alder. West. J. Appl. For. 22: 61-66.

Honer T.G., 1965. A new total cubic foot volume function. For. Chron. 41: 476-493.

Jiang L., Brooks J.R., and Hobbs G.R., 2007. Using crown ratio in yellow-poplar compatible taper and volume equations. North. J. Appl. For. 24: 271-275.

Kozak A., 1988. A variable-exponent taper equation. Can. J. For. Res. 18: $1363-1368$.

Kozak A., 1998. Effects of upper stem measurements on the predictive ability of a variable-exponent taper equation. Can. J. For. Res. 28: 1078-1083.

Kozak A., 2004. My last words on taper equations. For. Chron. 80: 507514.

Kozak A. and Smith J.H.G., 1993. Standards for evaluating taper estimating systems. For. Chron. 69: 438-444.

Kozak A., Munro D.D., and Smith J.H.G., 1969. Taper functions and their application in forest inventory. For. Chron. 45: 278-283.

Lappi J., 2006. A multivariate, nonparametric stem-curve prediction method. Can. J. For. Res. 36: 1017-1027.

Larson B.C., 1963. Stem form development of forest trees. For. Sci. Monogr. 5: 1-42.

Leites L.P. and Robinson A.P., 2004. Improving taper equations of loblolly pine with crown dimensions in a mixed-effects modeling framework. For. Sci. 50: 204-212.

Maguire D.A., Brissette J., and Gu L., 1998. Crown structure and growth efficiency of red spruce in uneven-aged, mixed species stands in Maine. Can. J. For. Res. 28: 1233-1240.

Maguire D.A. and Batista J.L.F., 1996. Sapwood taper models and implied sapwood volume and foliage profiles for coastal Douglas-fir. Can. J. For. Res. 26: 849-863.

Max T.A. and Burkhart H.E., 1976. Segmented polynomial regression applied to taper equations. For. Sci. 22: 283-289.

McWilliams W.H., Butler B.J., Caldwell L.E., Griffith D.M., Hoppus M.L., Laustsen K.M., Lister A.J., Lister T.W., Metzler J.W., Morin R.S., Sader S.A., Stewart L.B., Steinman J.R., Westfall J.A., Williams D.A., Whitman A., and Woodall C.W., 2005. The forests of Maine: 2003. Resource Bulletin NE-164. US Department of Agriculture, Forest Service, Northeastern Research Station, Newton Square, PA, $188 \mathrm{p}$.

Meyer S.R., 2005. Leaf area as a growth predictor of Abies balsamea and Picea rubens in managed stands in Maine. Master's thesis, University of Maine, Orono, $117 \mathrm{p}$.
Muhairwe C.K, LeMay V.M., and Kozak A., 1994. Effects of adding tree, stand, and site variables to Kozak's variable-exponent taper equation. Can. J. For. Res. 24: 252-259.

Ozcelik R., 2008. Comparison of formulae for estimating tree bole volumes of Pinus sylvestris. Scand J. For Res. 23: 412-418.

Pace M.D., 2003. Effect of stand density on behavior of leaf area prediction models for eastern white pine (Pinus strobus L.) in Maine. Master's thesis, University of Maine, Orono, 69 p.

Phillips L.M., 2002. Crop tree growth and quality twenty-five years after precommercial thinning in a northern conifer stand. Master's thesis, University of Maine, Orono, $88 \mathrm{p}$.

Pinherio J.C. and Bates D.M., 2000. Mixed-effects models in S and SPlus. Springer-Verlag, New York, NY.

Pitt D. and Lanteigne L., 2008. Long-term outcome of precommercial thinning in northwestern new Brunswick: growth and yield of balsam fir and red spruce. Can. J. For. Res. 38: 592-610.

Rojo A., Perales X., Sanchez-Rodriguez F., Alvarez-Gonzalez J.G., and von Gadow K., 2005. Stem taper functions for maritime pine (Pinus pinaster Ait.) in Galicia (northwestern Spain). Eur. J. For. Res. 25: 177-186.

Sharma M. and Parton J., 2009. Modeling stand density effects on taper for jack pine and black spruce plantations using dimensional analysis. For. Sci. 55: 268-282.

Sharma M. and Zhang S.Y., 2004. Variable-exponent taper equations for jack pine, black spruce, and balsam fir in eastern Canada. Can. J. For. Res. 198: 39-53.

Shaw D.J., Meldahl R.S., Kush J.S., and Somers G.L., 2003. A tree taper model based on similar triangles and use of crown ratio as a measure of form in taper equations for longleaf pine. Tech. Rep., US Forest Service Southern Research Station General Technical Report SRS66, Asheville, NC, 8 p.

Thomas C.E. and Parresol B.R., 1991. Simple, flexible trigonometric taper equations. Can. J. For. Res. 21: 1132-1137.

Trincado G. and Burkhart H.E., 2006. A generalized approach for modeling and localizing stem profile curves. For. Res. 52: 670-682.

Valenti M.A. and Cao Q.V., 1986. Use of crown ratio to improve loblolly pine taper functions. Can. J. For. Res. 16: 1141-1145.

Valentine H.T. and Gregoire T.G., 2001. A switching model of bole taper. Can. J. For. Res. 31: 1400-1409.

Vicary B.P., Brann T.B., and Griffin R.H., 1984. Polymorphic site index curves for even-aged spruce-fir stands in Maine. Maine Agricultural Experiment Station Bulletin 802. University of Maine, Orono, 33 p.

Walters D.K. and Hann D.W., 1986. Taper equations for six conifer species in southwest Oregon. Research Bulletin 56, Forest Research Laboratory, Oregon State University, Corvallis, OR. 36 p.

Weiskittel A.R., Kenefic L.S, Seymour R.S, and Phillips L., 2009, Longterm effects of precommercial thinning on the stem dimensions form, volume, and branch characteristics of red spruce and balsam fir crop trees in Maine, USA. Silva Fenn. 43: 397-409.

Zakrzewski W.T., 1999. A mathematically tractable stem profile model for jack pine in Ontario. North. J. Appl. For. 16: 138-143.

Zhang Y., Borders B.E., and Bailey R.L., 2002. Derivation, fitting, and implication of a compatible stem taper-volume-weight system for intensively managed, fast growing loblolly pine. For. Sci. 48: 595-607. 